\begin{tabular}{|c|c|c|}
\hline $\begin{array}{l}\text { EXCELLENT } \\
\text { PUBLISHERS } \\
\end{array}$ & $\begin{array}{l}\text { International Journal of Current Research } \\
\text { and Academic Review } \\
\text { ISSN: 2347-3215 (Online) } \\
\text { Journal homepage: holtp://www.ijcrar.com } 5 \text { (May-2017) }\end{array}$ & 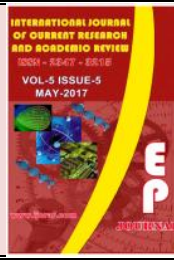 \\
\hline
\end{tabular}

doi: $\underline{\text { https://doi.org/10.20546/ijcrar.2017.505.003 }}$

\title{
Some Preliminary Observations on Abundance of Black Kite (Milvus migrans) and Brahminy Kite (Haliastur indus) in Kerala, South India
}

\author{
Binu Chullakattil $^{1^{*}}$ and K. Seedikkoya ${ }^{2}$ \\ ${ }^{I}$ Research and Development Centre, Bharathiar University, Coimbatore-641 046, India \\ ${ }^{2}$ M.E.S.Mampad College, Malappuram, Pin-676 542, Kerala, India \\ *Corresponding author
}

\begin{abstract}
The Black Kites [Milvus migrans] and Brahminy kites (Haliastur indus) are found in a variety of habitats, from wooded streams to open plains and are commonly seen in and around remote towns. The Present study shows that there is a considerable decline in the abundance of Black kites during heavy monsoon [June- September]. Thereafter the number gradually increases from October to May to reach its peak during March and April. The study indicates that there is a local migration among Black kites during South-West monsoon. Such a trend is not shown by Brahminykites. The probable reasons are also discussed.
\end{abstract}

\author{
Article Info \\ Accepted: 05 May 2017 \\ Available Online: 20 May 2017 \\ Keywords \\ Milvus migrans, Habitats, Haliastur \\ indus, Southwest monsoon, Streams, \\ Migration.
}

\section{Introduction}

The Black Kites are found in a variety of habitats, from wooded streams to open plains, and is often observed in and around remote towns. It is a medium-sized raptor. It preys on lizards, small mammals and insects, especially grasshoppers and is also is a scavenger (Ali 2002). Brahminy Kites are the birds of the coast, particularly mangrove swamps and estuaries. It is sometimes seen over forests and along rivers. Brahminy Kite feeds on carrion, insects and fish (Ali 2002). The abundance of black kite and Brahminy kite (Haliastur indus) depends mostly on food source (Bell 1985) and mostly they rest on roadside building or branches of trees which are seen situated on the roadside. Since Milvus migransand Haliastur indus are scavenging in habit, they are highly adaptable as an opportunistic feeder (Geroudet 1965; Delibes 1975, Arroyo 1978, Jones and Manez 1990). Studies on abundance and fluctuation of the above two species of birds is scanty except for a few reports by
Walz (2000), Walz and Sammulung (2005). In this context this study is significant.

\section{Materials and Methods}

The studies on abundance of the two species were conducted by roadside line transect method (Herremans et al., 2001) travelling a distance of of $50 \mathrm{kms}$ from Malappuram town to Kozhikode Mofussil bus stand thrice in every month and it lasted for a period from March 2013 to December 2015. Bird counts were taken byusing binoculars of magnification 10 X 50 .

\section{Study area}

The entire study area of $50 \mathrm{~km}$ was split into ten small bits of $5 \mathrm{kms}$ each for convenience of counting. The ten points covered under observation lie between Malappuram town- Melmuri, Melmuri-Athanikkal, 
Athanikkal- Mongam, Mongam-Musliarangadi, Musliarangadi-Kondotty, Kondotty-Kulathur, KulathurPulikkal, Pulikkal-Ramanattukara, RamanattukaraAreekkad and Areekkad-Kozhikode. The characteristics of the study area are shown in Table 1 .

\section{Results and Discussion}

The study shows that that there is considerable decline in the abundance of Black kites during heavy monsoon [June- September]. Thereafter the number gradually increases from October to May to reach its peak during March and April in 2013, 2014 and 2015 (Figures 1).

The variety of food consumed by black kites varies from region to region and across the seasons. Different types of carrion forms an important food item of this species but a variety of other live preys such as insects, reptiles, birds and small mammals, are also taken by this raptor (Nishant Kumar et al 2015). In urban areas, black kites are known to forage on human food scraps, garbage and mostly on waste dumps (Blanco, 1994; Pomeroy, 1975). They steal food from market stalls and even people.

Table.1 showing the characteristic features of study areas

\begin{tabular}{|c|c|c|c|}
\hline No & Points & Latitude/Longitude & Habitat Characteristics \\
\hline 1 & Malappuram - Melmuri & $\begin{array}{l}11.073189^{0} \mathrm{~N} / 76.074^{0} \mathrm{E} \\
10.955^{0} \mathrm{~N} / 76.0995^{0} \mathrm{E}\end{array}$ & $\begin{array}{l}\text { Bus stand area, Township, Market area, Paddy } \\
\text { fields, Hospital area, Largely Urbanized area }\end{array}$ \\
\hline 2 & Melmuri - Athanikkal & $11.012^{0} \mathrm{~N} / 75.992^{0} \mathrm{E}$ & Paddy fields, Streams, Rural area \\
\hline 3 & Athanikkal - Mongam & $11.1338^{0} \mathrm{~N} / 76.0349^{0} \mathrm{E}$ & $\begin{array}{l}\text { Moderately urbanized area, small Township, } \\
\text { fish market, paddy fields }\end{array}$ \\
\hline 4 & Mongam - Musliarangadi & $11.129^{0} \mathrm{~N} / 76.0029^{0} \mathrm{E}$ & $\begin{array}{l}\text { Moderately urbanized area, paddy fields, no } \\
\text { thick vegetation }\end{array}$ \\
\hline 5 & $\begin{array}{l}\text { Musliarangadi - Kondotty } \\
\text { [ Air Port Junction] }\end{array}$ & $11.2587^{0} \mathrm{~N} / 75.780^{0} \mathrm{E}$ & $\begin{array}{l}\text { Largely urbanized area Township with meat, } \\
\text { fish, vegetable market area, Hospital area, } \\
\text { reduced vegetation and paddy fields }\end{array}$ \\
\hline 6 & $\begin{array}{l}\text { Kondotty } \\
\text { [ Air Port Junction] - Kulathur }\end{array}$ & $11.4402^{0} \mathrm{~N} / 75.752^{0} \mathrm{E}$ & $\begin{array}{l}\text { Moderately urbanized area, paddy fields, thick } \\
\text { vegetation }\end{array}$ \\
\hline 7 & Kulathur - Pulikkal & $11.177^{0} \mathrm{~N} / 75.918^{0} \mathrm{E}$ & $\begin{array}{l}\text { Moderately urbanized area, reduced vegetation, } \\
\text { patchy distribution of paddy fields }\end{array}$ \\
\hline 8 & Puilkkal - Ramanattukara & $11.178^{0} \mathrm{~N} / 75.865^{0} \mathrm{E}$ & $\begin{array}{l}\text { Largely urbanized area, Large Township, meat, } \\
\text { fish, vegetable market area, Hospital area, } \\
\text { reduced vegetation and paddy fields }\end{array}$ \\
\hline 9 & Ramanattukara- Areeekkad & $11.209^{0} \mathrm{~N} / 75.812^{0} \mathrm{E}$ & $\begin{array}{l}\text { Moderately urbanized area, patchy distribution } \\
\text { of paddy fields, township, Hospital area, river } \\
\text { area }\end{array}$ \\
\hline 10 & Areekkad - Kozhikkode Town & $11.258^{0} \mathrm{~N} / 75.780^{\circ} \mathrm{E}$ & $\begin{array}{l}\text { Highly urbanized area, market area, Hospital } \\
\text { area, canal area reduced paddy fields and } \\
\text { vegetation, large township, railway track }\end{array}$ \\
\hline
\end{tabular}


Fig.1 showing the abundance of Black kite and Brahminy kite in the study areas

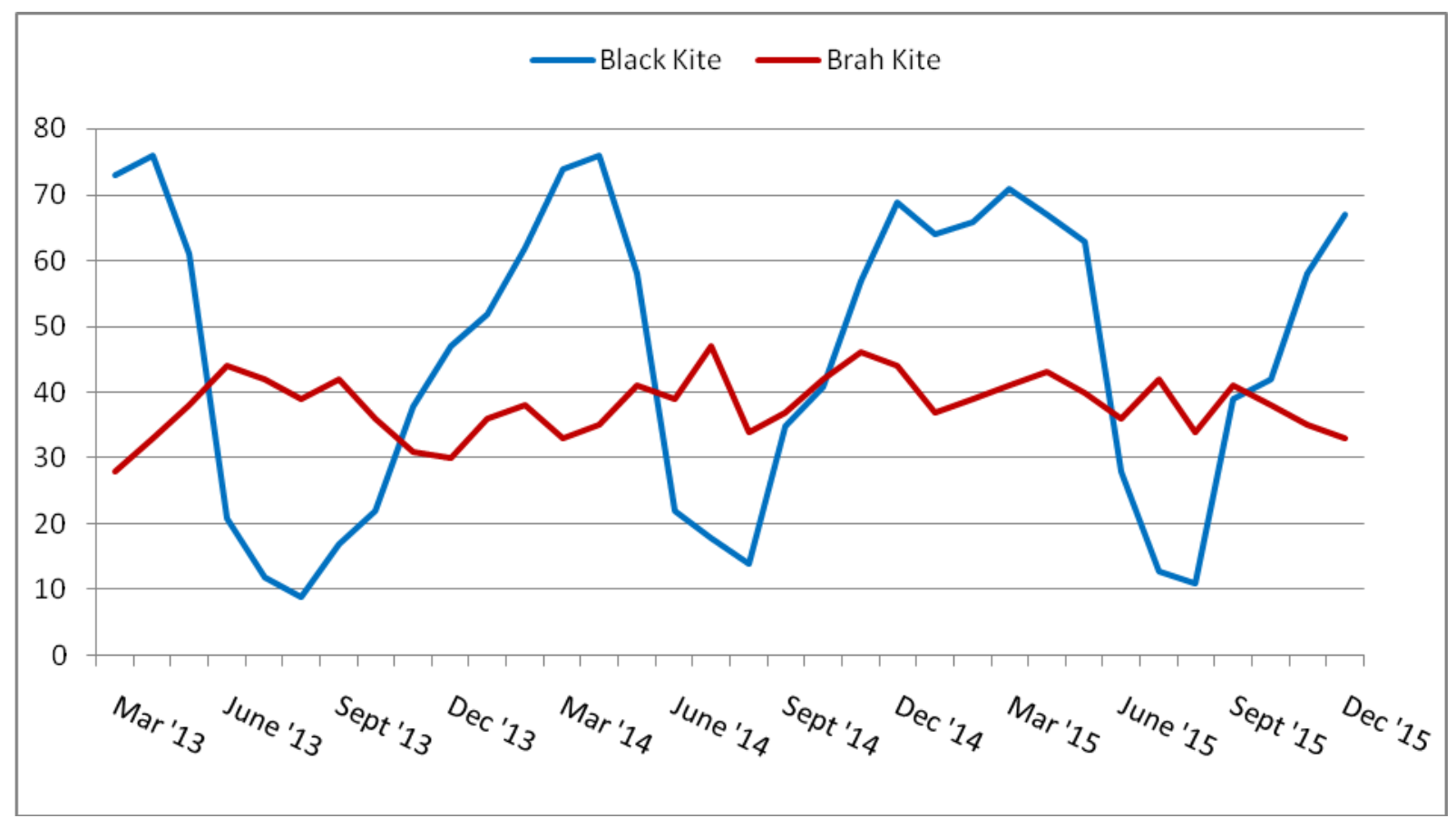

Since Black kites are mainly scavengers, washing out of wastes containing food scraps during heavy rain from the road side and open areas may cause the depletion of both the quality and quantity of the food which in turn lead the adult birds to take a shifting movement. So the adults are seen least in abundance during heavy monsoon. A few juveniles and sub adults which are remained in the above habitats under study, depend on the available resources after the adults are shifted.

The juveniles that remained were identified on the basis of juvenile plumage coloration and their mode of flight because of the loss of several flight feathers or irregular molt patterns (Sylvan, 1977). The decrease in the number of Black kites associated with heavy rain is also reported by Balmer and Kirwan (2003). They reported that this movement is in groups (Farago, 2000) but not seeing in a single day. The exact location to which these birds are shifted is to be confirmed only through ringing or banding.

The number of Brahminy kites remained more or less same throughout the study periods (Figure 1). Brahminy kites not being a major scavenger, they prey upon both aquatic and terrestrial food species. Hence during heavy monsoon, food may not be a constraint for the free distribution of Brahminy kites. Hence they remain in the same habitat without showing any local migration.

\section{References}

Ali, S. (2002). Text book of Indian Birds. $13^{\text {th }}$ edn. Pp. 95-96

Arroyo, B. (1980). La alimentation del Milano negro Milvus migrans. en unalocali dad de Espana Central Ardeola, 25: 47-57

Balmer, D and Kirwan, G.M. (2003). Raptor migration monitoring in Georgia, Sand grouse, 25: 89

Bell, H.L. (1985). Distribution and habits of kites Milvus migrans, Haliastur Sphenurus and H.indus in papua New Guinea, Corella, 9: 37-44 .

Blanco, G. (1994). Seasonal abundance of black kites associated with the rubbish dump of Mandrid Spain. J. Raptor Res., 28: 242-245

Delibes, M. (1975). Alimentaciondel Milano negro Milvus migrans, en Donana (Huelva, Espana), Ardeola, 21: 183-207

Farago, I.C. (2000). Unusually large migration of Black kite Milvus migrans in South Zala $\neq \mathrm{ZOK}, 4(1)$ : 24-125

Geroudet, P. (1965). Les rapacesdiurnes et nocturnes d' Europe. Delachauxet Niestle, Newchatel, Switzerland.

Herremans, M., Herrremans Tonnoeyr, D. (2001). Road side abundance of raptors in the Western Cape Province, South Africa: a three decade comparison. Ostrich, 72 (1\&2): 96-100. 
Jones, A.M. and Manez, M. (1990). Cannibalizm by Black kite Milvus migrans, J. Raptor. Res., 24: $28-29$

Kumar, N., Mohan, D., Jhala, V.Y., Qureshi, Q. (2014). Density,layingdate,breeding success and diet of Black Kites Milvus migransgovinda in the city of Delhi(India). Bird Study: 61; 1

Pomeroy, D.E. 1975. Birds as scavengers of refuse in uganda. Ibis, 117; 69-81.
Sylven, M. (1977). Age determination of red kite Milvusmilvus and black kite Milvus migrans. VarFagdlvarld, 36: 33-37.

Walz, J. (2000). Terrotory size, population density and population trends of red and black kites, interpretations and resulting conservation measures. OrnithologischeJahreshefte $\mathrm{f} r$ Baden W rttemberg, 16: 189.

Walz, J. and Sammlung, V. (2005). Red and Black kites flexible hunters with slope to sociability. Weibelsheim. German y AULA-Verlag. 1.

How to cite this article:

Binu Chullakattil and K. Seedikkoya. 2017. Some Preliminary Observations on Abundance of Black Kite (Milvus migrans) and Brahminy Kite (Haliastur indus) in Kerala, South India. Int.J.Curr.Res.Aca.Rev. 5(5), 15-18. doi: https://doi.org/10.20546/ijcrar.2017.505.003 